\title{
IMPLEMENTASI KOOPERATIF NHT MENINGKATKAN AKTIVITAS DAN HASIL BELAJAR SENAM LANTAI GULING DEPAN DAN SIKAP LILIN
}

\author{
I Made Dwi Antara ${ }^{1, *}$ \\ 1 Universitas Pendidikan Ganesha
}

\section{Abstrak}

Penelitian ini bertujuan meningkatkan aktivitas dan hasil belajar senam lantai guling depan dan sikap lilin melalui implementasi model pembelajaran kooperatif tipe NHT pada Peserta didik kelas XII.MIPA.5 SMA Negeri 2 Singaraja tahun pelajaran 2017/2018. Penelitian ini adalah penelitian tindakan kelas (guru sebagai peneliti) dilaksanakan dalam dua siklus, terdiri dari rencana tindakan, pelaksanaan tindakan, observasi atau evaluasi dan refleksi. Subjek penelitian adalah peserta didik kelas XII.MIPA.5 SMA Negeri 2 Singaraja tahun pelajaran 2017/2018, berjumlah 30 orang dengan 18 orang putra dan 12 orang putri. Data dianalisis menggunakan analisis statistik deskriptif. Berdasarkan hasil analisis data didapatkan rata-rata aktivitas belajar senam lantai guling depan dan sikap lilin secara klasikal pada observasi awal 6,2(cukup aktif), pada siklus I meningkat menjadi 7( aktif), dan 7,9 (aktif) pada siklus II. Sedangkan persentase ketuntasan hasil belajar kompetensi pengetahuan dari observasi awal sebesar 20\% (tuntas), pada siklus I menjadi 66,7\%(tuntas) dan $100 \%$ (tuntas) pada siklus II. Peningkatan hasil belajar secara signifikan juga terjadi pada kompetensi sikap dan kompetensi keterampilan. Berdasarkan hasil analisis data dan pembahasan disimpulkan bahwa aktivitas dan hasil belajar senam lantai guling depan dan sikap lilin meningkat melalui implementasi model pembelajaran kooperatif tipe NHT pada peserta didik kelas XII.MIPA.5 SMA Negeri 2 Singaraja tahun pelajaran 2017/2018. Disarankan kepada guru PJOK agar menggunakan model pembelajaran kooperatif tipe NHT karena dapat meningkatkan aktivitas dan hasil belajar senam lantai guling depan dan sikap lilin peserta didik.
\end{abstract}

Kata-kata Kunci:

Kooperatif, NHT.

\section{Pendahuluan}

Kurikulum terus disesuaikan, berbagai pendekatan dan metode pembelajaran disempurnakan, pembelajaran tambahan jam ekstra terus dilakukan, namun hasil belajar pendidikan jasmani, olahraga dan kesehatan (PJOK) belum sesuai dengan harapan. Salah satu penyebabnya adalah pelaksanaan pembelajaran mata pelajaran PJOK sering mengalami masalah. Bagi siswa masalah sering dialami karena sebagian besar siswa sudah beranggapan bahwa PJOK merupakan pelajaran yang memerlukan tenaga besar, perlu kekuatan tubuh yang cukup dan memerlukan keterampilan khusus disamping itu kebanyakan siswa di setiap jenjang pendidikan masih banyak berpandangan bahwa PJOK merupakan mata pelajaran yang sulit dan sering menimbulkan masalah dalam belajar. Padahal berbagai upaya terpadu telah dilakukan pemerintah dan pihak-pihak yang peduli pendidikan dalam rangka meningkatkan kualitas pendidikan, namun semua usaha tersebut belum membuahkan hasil yang optimal. Perencanaan pembelajaran yang dibuat dan yang akan disajikan di kelas masih kurang mengarah pada upaya meningkatkan aktivitas dan hasil belajar PJOK siswa.

Pada pelajaran PJOK terutama di SMA, siswa cenderung kurang aktif untuk berpartisipasi dalam proses pembelajaran, hal ini terbukti dari aktvitas dan hasil belajar gerak yang diperoleh siswa kurang memuaskan atau belum memenuhi sasaran yang ditunjukkan dengan belum dikuasainya teknik-teknik gerak yang diajarkan. Siswa cenderung menyepelekan pelajarn PJOK, sebab mereka lebih terkonsentrasi pada mata pelajaran yang diujikan pada ujian nasional. 
Berdasarkan hasil observasi awal yang dilakukan peneliti pada hari Sabtu, 26 Agustus di kelas XII.MIPA.5 SMA Negeri 2 Singaraja tahun pelajaran 2017/2018, aktivitas belajar 30 peserta didik (11 peserta didik perempuan dan 19 peserta didik laki-laki) pada materi senam lantai guling depan dan sikap lilin yang diperoleh pada saat observasi tergolong cukup aktif. Dapat dilihat dari komponen aktivitas belajar peserta didik yang terdiri dari kegiatan visual, lisan, mendengarkan, metrik, mental dan emosional. Berdasarkan hasil pengamatan dari keenam komponen aktivitas tersebut didapatkan hasil persentase sebagai berikut:

Peserta didik pada kategori sangat aktif tidak ada (0\%), 14 orang $(46,7 \%)$ berada dalam kategori tingkat aktivitas yang aktif, 10 orang (33,3\%) berada dalam kategori tingkat aktivitas yang cukup aktif, 6 orang $(20 \%)$ berada dalam kategori tingkat aktivitas yang kurang aktif, dan tidak ada orang $(0 \%)$ berada dalam kategori tingkat aktivitas yang sangat kurang aktif, dengan persentase ketuntasan 14 orang $(46,7 \%)$ tuntas dan 16 orang $(53,3 \%)$ tidak tuntas. Berdasarkan data di atas, maka peneliti bisa mengetahui rata-rata klasikal aktivitas belajar senam lantai guling depan dan sikap lilin sebesar 6,2 yang tergolong dalam kategori cukup aktif. Sehingga dapat diketahui berapa banyak peserta didik yang tuntas dan peserta didik tidak tuntas.

Jika dilihat dari hasil observasi, ketuntasan hasil belajar untuk aspek pengetahuan, peserta didik yang berada pada kategori baik 6 orang $(20 \%)$, dan pada kategori cukup baik 24 orang $(80 \%)$. Jadi jumlah siswa yang tuntas dalam senam lantai guling depan dan sikap lilin aspek pengetahuan secara klasikal yaitu 6 orang $(20 \%)$ tuntas dan 24 orang $(80 \%)$ tidak tuntas, dengan presentase nilai rata-rata hasil belajar secara klasikal yaitu $80 \%$ yang berada pada kategori tidak tuntas. Dengan menganalisa data hasil belajar kompetensi pengetahuan peserta didik secara keseluruhan terlihat belum memenuhi sasaran, karena belum memenuhi standar kriteria ketuntasan minimal (KKM) sekolah untuk mata pelajaran PJOK sebesar 70\% ketuntasan klasikal. Permasalahan yang muncul pada aspek pengetahuan adalah kurangnya pemahaman peserta didik mengenai senam lantai guling depan dan sikap lilin, hal ini disebabkan oleh kurangnya perhatian peserta didik pada saat guru menjelaskan dan pembelajaran masih dominan guru yang lebih aktif.

Ketuntasan hasil belajar untuk aspek keterampilan, peserta didik yang berada pada kategori baik sebanyak 8 orang $(26,7 \%)$, cukup baik sebanyak 16 orang $(53,3 \%)$ dan kurang baik sebanyak 6 orang (20\%). Jadi jumlah siswa yang tuntas dalam senam lantai guling depan dan sikap lilin aspek keterampilan secara klasikal yaitu 8 orang $(26,7 \%)$ tuntas dan 22 orang $(73,3 \%)$ tidak tuntas, dengan presentase nilai rata-rata hasil belajar secara klasikal yaitu $73,3 \%$ yang berada pada kategori tidak tuntas. Dengan menganalisa data hasil belajar kompetensi keterampilan peserta didik secara keseluruhan terlihat hasil belajar kompetensi keterampilan belum memenuhi target, karena belum memenuhi standar KKM sekolah untuk mata pelajaran PJOK sebesar 70\% ketuntasan klasikal. Pada aspek keterampilan permasalahan yang terjadi adalah masih banyak peserta didik yang salah dalam melakukan senam lantai guling depan dan sikap lilin yaitu: (1) pada saat berguling kepala dipakai sebagai tumpuan, (2) kaki tidak ditekuk, (3) pada sikap lilin kaki tidak mau lurus karena kesalah pada tumpuan.

Sedangkan ketuntasan hasil belajar untuk aspek sikap, peserta didik yang berada pada kategori baik 5 orang $(16,7 \%)$ dan cukup baik 25 orang $(83,3 \%)$. Jadi jumlah siswa yang tuntas dalam senam lantai guling depan dan sikap lilin aspek sikap secara klasikal yaitu 5 orang $(16,7 \%)$ tuntas dan 25 orang $(83,3 \%)$ tidak tuntas, dengan presentase nilai rata-rata hasil belajar secara klasikal yaitu $83,3 \%$ yang berada pada kategori tidak tuntas. Dengan menganalisa data hasil belajar kompetensi sikap peserta didik secara keseluruhan terlihat sudah memenuhi ketuntasan, karena sudah memenuhi standar KKM sekolah untuk mata pelajaran PJOK sebesar 70\% ketuntasan klasikal. Jadi adanya peserta didik yang bermasalah pada hasil belajar disebabkan oleh (1) dari segi kerjasama, peserta didik masih kurang untuk melakukan kerjasama didalam pembelejaran dan cenderung individual, (2) dari segi disiplin, peserta didik masih banyak yang berpakaian kurang rapi, terlambat saat datang dan melakukan kegiatan diluar materi saat pembelajaran, (3) dari segi tanggung jawab, peserta didik kurang bertanggung jawab didalam pemakain sarana pembelajaran.

Jadi jika dilihat dari rata-rata aktivitas dan hasil belajar senam lantai guling depan dan sikap lilin di atas dapat disimpulkan bahwa, aktivitas dan hasil belajar senam lantai guling depan dan sikap lilin pada kelas XII.MIPA.5 SMA Negeri 2 Singaraja tidak tuntas. Hal ini disebabkan implementasi model pembelajaran yang belum efektif terhadap materi yang disajikan. Model pembelajaran yang diimplementasikan belum melibatkan atau merangsang peserta didik untuk lebih aktif dan kreatif selama proses pembelajaran berlangsung. Berdasarkan permasalahan di atas, peneliti mencoba memberikan salah satu alternatif pemecahan masalah yaitu dengan menerapkan model pembelajaran kooperatif tipe Numbered Head Together (NHT) dalam pembelajaran PJOK pada materi senam lantai guling depan dan sikap lilin. Ketertarikan peneliti menerapkan model pembelajaran kooperatif tipe NHT ini karena (1) model pembelajaran kooperatif dengan tipe NHT adalah model pembelajaran yang sederhana, sehingga 
model pembelajaran kooperatif ini cocok diterapkan pada peserta didik kelas XII.MIPA.5 SMA Negeri 2 Singaraja yang belum pernah melakukan pembelajaran kooperatif tipe NHT, (2) pada model pembelajaran ini peserta didik lebih banyak mempunyai kesempatan diskusi kelompok, masing-masing peserta didik memberikan partisipasinya secara maksimal dan setiap peserta didik mempunyai tanggung jawab perseorangan untuk menguasai materi dengan sebaik-baiknya, (3) model pembelajaran kooperatif dengan tipe NHT mengajak peserta didik untuk belajar aktif dan berani dalam mengeluarkan pendapat dalam diskusi kelompok. Apabila ada suatu konsep yang belum dimengerti dan dipahaminya, peserta didik dapat saling isi mengisi dengan peserta didik lain, saling bertukar pikiran sehingga diharapkan konsep yang dimiliki peserta didik benar-benar dapat dipahami dengan baik. Suasana belajar akan lebih kondusif, yang akhirnya berpengaruh terhadap aktivitas dan hasil belajar.

Pemilihan tentang model pembelajaran NHT ini juga dikuatkan oleh hasil penelitian dari penelitipeneliti sebelumnya diantaranya (1) Penelitian yang dilakukan oleh Sanjaya, I.P.E.Y (2013 :123) dalam skripsinya yang menyimpulkan motivasi dan hasil belajar teknik Lompat jauh gaya menggantungmeningkat melalui penerapan model pembelajaran kooperatif tipe NHT pada peserta didik kelas X.5 SMA Negeri 1 Negara tahun pelajaran 2012/2013, (2) Penelitian yang dilakukan oleh Bawa, I.M.L (2012:116) dalam skripsinya yang menyimpulkan aktivitas dan hasil belajar teknik dasar passing sepak bola meningkat melalui penerapan model pembelajaran kooperatif tipe NHT pada peserta didik kelas X.1 SMK Negeri 2 Singaraja tahun pelajaran 2011/2012, (3) Penelitian yang dilakukan oleh Tirtawati, N.W (2013 :103) dalam skripsinya yang menyimpulkan motivasi dan hasil belajar lompat jauh gaya menggantung meningkat melalui penerapan model pembelajaran kooperatif tipe NHT pada peserta didik kelas XI IPA 3SMA Negeri 2 Bangli tahun pelajaran 2012/2013.

Berdasarkan uraian di atas, maka peneliti bermaksud mengadakan penelitian dengan judul "Implementasi Model Pembelajaran Kooperatif Tipe NHT untuk Meningkatkan Aktivitas dan Hasil Belajar Senam Lantai Guling Depan dan Sikap Lilin pada Peserta Didik Kelas XII.MIPA.5 SMA Negeri 2 Singaraja Tahun Pelajaran 2017/2018".

\section{Metode}

Jenis penelitian yang digunakan adalah penelitian tindakan kelas. Menurut Arikunto dkk, (2008: 23) dikarenakan ada tiga kata yang membentuk pengertian tersebut, maka ada tiga pengertian yang dapat diterangkan sebagai berikut. a) Penelitian, menunjuk pada suatu kegiatan mencermati suatu objek dengan menggunakan cara dan aturan metodologi tertentu untuk memproleh data atau informasi yang bermaanfat dalam meningkatkan mutu suatu hal yang menarik minat dan penting bagi peneliti, b) Tindakan, menunjuk pada sesuatu gerak kegiatan yang disengaja dilakukan dengan tujuan tertentu, c) Kelas, dalam hal ini tidak terikat pada pengertian ruang kelas, tetapi dalam pengertian yang lebih spesifik.

Dengan menggabungkan batasan pengertian tiga kata inti, yaitu (1) penelitian, (2) tindakan, (3) kelas, dapat disimpulkan bahwa penelitian tindakan kelas merupakan suatu pencermatan terhadap kegiatan belajar berupa sebuah tindakan, yang sengaja dimunculkan dan terjadi dalam sebuah kelas secara bersama.

Oja dan Smulyan membedakan adanya empat bentuk penelitian tindakan, yaitu (1) guru sebagai peneliti, (2) penelitian Tindakan Kolaboratif, (3) simultan-Terintregasi, (4) administrasi Sosial Eksperimental (Kanca, I Nyoman, 2010: 115). Dalam penelitian ini bentuk penelitian tindakan yang digunakan adalah guru sebagai peneliti. Karena peneliti sudah menjadi guru, maka dalam penelitian ini menggunakan bentuk penelitan peneliti sebagai guru, karena dalam bentuk PTK yang memandang guru sebagai peneliti mempunyai ciri-ciri penting yaitu sangat berperannya guru itu sendiri dalam proses PTK. Tujuan utama PTK adalah untuk memperbaiki dan meningkatkan mutu profesional guru didalam proses pembelajaran.

\section{Hasil dan Pembahasan}

Penelitian ini dilaksanakan dari hari Sabtu tanggal 09 September 2017 sampai dengan hari Sabtu tanggal 30 September 2017, yang dilaksanakan setiap pukul 05.30-07.15 wita, bertempat di lapangan halaman SMA Negeri 2 Singaraja, dengan subjek penelitiannya adalah peserta didik kelas XII.MIPA.5 SMA Negeri 2 Singaraja Tahun Pelajaran 2017/2018 yang berjumlah 30 orang yang terdiri dari 18 orang peserta didik putra dan 12 orang peserta didik putri. Penelitian ini dilaksanakan sebanyak dua siklus, disetiap siklus terdapat dua kali pertemuan. Siklus I pertemuan pertama dilaksanakan pada hari sabtu 09 September 2017 untuk pengambilan data aktivitas belajar peserta didik dan pertemuan kedua dilaksanakan pada hari sabtu 16 September 2017 untuk pengambilan data aktivitas dan hasil belajar peserta didik. Sedangkan siklus II pertemuan pertama dilaksanakan pada hari sabtu 23 September 2017 
untuk pengambilan data aktivitas belajar peserta didik dan pertemuan kedua dilaksanakan pada hari sabtu 30 September 2017 untuk pengambilan data aktivitas dan hasil belajar peserta didik, yang bertempat di lapangan halaman SMA Negeri 2 Singaraja, untuk pengambilan data aktivitas dan hasil belajar peserta didik melibatkan seorang Observer yaitu guru PJOK SMA Negeri 2 Singaraja.

Tabel 1.

Hasil Analisis Data Aktivitas Belajar Senam Lantai Guling Depan dan Sikap Lilin

Siklus I

\begin{tabular}{|c|c|c|c|c|c|c|}
\hline No & Kriteria & $\begin{array}{l}\text { Jumlah } \\
\text { Peserta } \\
\text { Dididk }\end{array}$ & Persentase & Kategori & \multicolumn{2}{|c|}{ Keterangan } \\
\hline 1 & - & - & - & Sangat aktif & 23 & Orang \\
\hline 2 & $\begin{array}{c}X 9 \\
7 \bar{X}<9\end{array}$ & 23 & $76,7 \%$ & Aktif & \multicolumn{2}{|c|}{ Aktif $(76,7 \%)$} \\
\hline 3 & $5 \bar{X}<7$ & 7 & $23,3 \%$ & Cukup Aktif & 7 & Orang \\
\hline $\begin{array}{l}4 \\
5\end{array}$ & $\begin{array}{c}3 \bar{X}<5 \\
\bar{X}<3\end{array}$ & - & $\begin{array}{l}- \\
-\end{array}$ & $\begin{array}{c}\text { Kurang Aktif } \\
\text { Sangat Kurang } \\
\text { Aktif }\end{array}$ & $\begin{array}{l}\text { Peserta } \\
\text { Tidak } \\
(23,3 \%)\end{array}$ & $\begin{array}{r}\text { Didik } \\
\text { Aktif }\end{array}$ \\
\hline & Total & 30 & $100 \%$ & & $\begin{array}{r}30 \text { Pes } \\
\text { Dididk (1 }\end{array}$ & $\begin{array}{l}\mathrm{rta} \\
00 \%)\end{array}$ \\
\hline
\end{tabular}

Dari tabel 1. di atas dapat dilihat bahwa, peserta didik yang berada pada kategori sangat aktif tidak ada, kategori aktif 23 orang $(76,7 \%)$, kategori cukup aktif 7 orang (23,3\%), kurang aktif tidak ada begitu juga dengan siswa yang sangat kurang aktif.

Dari hasil analisis data diatas maka dapat dikatakan bahwa implementasi model pembelajaranan kooperatif tipe NHT efektif untuk meningkatkan aktivitas belajar senam lantai guling depan dan sikap lilin, hal ini dapat dilihat dari presentase ketuntasan belajar yang mencapai 76,7\% (23 orang)

Tabel 2.

Hasil Analisis Data Hasil Belajar Aspek Pengetahuan Senam Lantai Guling Depan dan Sikap Lilin pada Siklus I

\begin{tabular}{|c|c|c|c|c|c|}
\hline No & $\begin{array}{l}\text { Rentang } \\
\text { Skor }\end{array}$ & Predikat & $\begin{array}{c}\text { Jumlah } \\
\text { Peserta } \\
\text { Didik }\end{array}$ & Persentas & $\begin{array}{r}\text { Jumlah Ketuntasan } \\
\text { Peserta Didik }\end{array}$ \\
\hline 1 & \multicolumn{2}{|c|}{$90-100$ A (Sangat Baik) } & 1 Orang & $3,4 \%$ & Orang Peserta \\
\hline 2 & $80-89$ & B (Baik) & 11 Orang & $36,6 \%$ & \multirow[t]{2}{*}{ Didik $66,7 \%$ Tuntas } \\
\hline 3 & $70-79$ & C (Cukup Baik) & 8 Orang & $26,7 \%$ & \\
\hline 4 & $>70$ & D (Kurang Baik) & 10 Orang & $33,3 \%$ & $\begin{array}{l}10 \text { Orang Peserta } \\
\text { Didik 33,3\% Tidak } \\
\text { Tuntas } \\
\quad 30 \text { Orang Peserta }\end{array}$ \\
\hline \multicolumn{3}{|c|}{ Jumlah } & 30 & $100 \%$ & Didik (100\%) \\
\hline
\end{tabular}

Berdasarkan tabel 2, hasil belajar aspek pengetahuan pada siklus I dengan materi senam lantai guling depan dan sikap lilin, diperoleh data hasil belajar dengan kategori individu sebagai berikut, 1 orang kategori sangat baik $(3,4 \%), 11$ orang peserta didik $(36,6 \%)$ memperoleh nilai dengan kategori baik, 8 orang peserta didik $(26,7 \%)$ memperoleh nlai dengan kategori cukup, dan 10 orang peserta didik $(33,3 \%)$ memperoleh nilai dengan kategori kurang. 
Tabel 3.

Hasil Analisis Data Hasil Belajar Aspek Sikap Senam Lantai Guling Depan dan Sikap Lilin pada siklus I

\begin{tabular}{|c|c|c|c|c|c|}
\hline No & Rentang Skor & Predikat & $\begin{array}{l}\text { Jumlah } \\
\text { Peserta } \\
\text { Didik }\end{array}$ & Persentas & $\begin{array}{l}\text { Jumlah } \\
\text { Ketuntasan } \\
\text { Peserta Didik }\end{array}$ \\
\hline 1 & $90-100$ & A & - & - & 27 Orang Peserta \\
\hline 2 & $80-89$ & B & 8 Orang & $26,7 \%$ & Didik Tuntas (90\%) \\
\hline 3 & $70-79$ & $\mathrm{C}$ & 19 Orang & $63,3 \%$ & \\
\hline 4 & $>70$ & $\mathrm{D}$ & 3 Orang & $10 \%$ & $\begin{array}{l}3 \text { Orang Peserta } \\
\text { Didik Tuntas }\end{array}$ \\
\hline & Jumlah & & 30 & $100 \%$ & $\begin{array}{c}30 \text { Orang Peserta } \\
\text { Didik }(100 \%)\end{array}$ \\
\hline
\end{tabular}

Berdasarkan tabei 3. di atas, hasil belajar aspek sikap pada siklus I dengan materi senam lantai guling depan dan sikap lilin, diperoleh data hasil belajar dengan kategori individu sebagai berikut, peserta didik dengan kategori sangat baik tidak ada, 8 orang peserta didik $(26,7 \%)$ memperoleh nilai dengan kategori baik, 19 orang peserta didik (63,3\%) dengan kategori cukup, dan 3 orang peserta didik (10\%) memperoleh nilai dengan kategori kurang.

Tabel 4.

Hasil Analisis Data Hasil Belajar Aspek Keterampilan Senam Lantai Guling Depan dan Sikap Lilin pada siklus I

\begin{tabular}{|c|c|c|c|c|c|}
\hline No & $\begin{array}{l}\text { Rentang } \\
\text { Skor }\end{array}$ & Predikat & $\begin{array}{c}\text { Jumlah } \\
\text { Peserta Didik }\end{array}$ & $\begin{array}{c}\text { Persenta } \\
\mathrm{s}\end{array}$ & $\begin{array}{c}\text { Jumlah Ketuntasan } \\
\text { Peserta Didik }\end{array}$ \\
\hline 1 & $90-100$ & $\begin{array}{l}\text { A (Sangat } \\
\text { Baik) }\end{array}$ & 4 Orang & $13,4 \%$ & $\begin{array}{l}25 \text { Orang Peserta } \\
\text { Didik } 83,3 \% \text { Tuntas }\end{array}$ \\
\hline 2 & $80-89$ & B (Baik) & 14 Orang & $46,6 \%$ & \\
\hline 3 & $70-79$ & $\begin{array}{l}\text { C (Cukup } \\
\text { Baik) }\end{array}$ & 7 Orang & $23,3 \%$ & \\
\hline 4 & $>70$ & $\begin{array}{l}\text { D (Kurang } \\
\text { Baik) }\end{array}$ & 5 Orang & $16,7 \%$ & $\begin{array}{l}5 \text { Orang Peserta } \\
\text { Didik 16,7\% Tidak } \\
\text { Tuntas }\end{array}$ \\
\hline \multicolumn{3}{|c|}{ Jumlah } & 30 & $100 \%$ & $\begin{array}{c}30 \text { Orang Peserta } \\
\text { Didik (100\%) }\end{array}$ \\
\hline
\end{tabular}

Berdasarkan tabel 4. hasil belajar aspek keterampilan pada siklus I dengan materi senam lantai guling depan dan sikap ilin, diperoleh data hasil belajar dengan kategori individu sebagai berikut, 4 orang kategori sangat baik (13,4\%), 14 orang (46,6\%) memperoleh nilai dengan kategori baik, 7 orang $(23,3 \%)$ memperoleh nilai dengan kategori cukup, dan 5 orang $(16,7 \%)$ memperoleh nilai dengan kategori kurang.

Tabel 5.

Hasil Analisis Data Aktivitas Belajar Senam Lantai Guling Depan dan Sikap Lilin pada Siklus II

\begin{tabular}{|c|c|c|c|c|c|}
\hline No & Kriteria & $\begin{array}{c}\text { Jumlah } \\
\text { Peserta } \\
\text { Dididk }\end{array}$ & Persentase & Kategori & Keterangan \\
\hline 1 & $X 9$ & 2 & $6,7 \%$ & Sangat aktif & $\begin{array}{c}28 \text { Orang Peserta } \\
\text { Didik Aktif }(93.3 \%)\end{array}$ \\
\hline 2 & $7 \bar{X}<9$ & 26 & $86,6 \%$ & Aktif & \\
\hline 3 & $5 \bar{X}<7$ & 2 & $6,7 \%$ & Cukup Aktif & 2 Orang Peserta Didik \\
\hline $\begin{array}{l}4 \\
5\end{array}$ & $3 \bar{X}<5$ & $\begin{array}{l}- \\
-\end{array}$ & - & $\begin{array}{l}\text { Kurang Aktif } \\
\text { Sangat Kurang }\end{array}$ & Tidak Aktif $(6,7 \%)$ \\
\hline
\end{tabular}


Dari tabel 5. di atas dapat dilihat bahwa, peserta didik yang berada pada kategori sangat aktif 2 orang $(6,7 \%)$, kategori aktif 26 orang $(86,6 \%)$, kategori cukup aktif 2 orang $(6,7 \%)$, dan tidak ada peserta didik yang berada dalam kategori kurang aktif, dan sangat kurang aktif.

Tabel 6.

Hasil Analisis Data Hasil Belajar Aspek Pengetahuan Senam Lantai Guling Depan dan Sikap Lilin pada Siklus II

\begin{tabular}{|c|c|c|c|c|c|}
\hline No & Rentang Skor & Predikat & $\begin{array}{c}\text { Jumlah } \\
\text { Peserta } \\
\text { Didik } \\
\end{array}$ & Persentase & $\begin{array}{c}\text { Jumlah } \\
\text { Ketuntasan } \\
\text { Peserta Didik } \\
\end{array}$ \\
\hline 1 & $90-100$ & $\begin{array}{l}\text { A (Sangat } \\
\text { Baik) }\end{array}$ & 6 Orang & $20 \%$ & $\begin{array}{l}30 \text { Orang Peserta } \\
\text { Didik } 100 \% \text { Tuntas }\end{array}$ \\
\hline 2 & $80-89$ & B (Baik) & 15 Orang & $50 \%$ & \\
\hline 3 & $70-79$ & $\begin{array}{l}\text { C (Cukup } \\
\text { Baik) }\end{array}$ & 9 Orang & $30 \%$ & \\
\hline \multirow[t]{2}{*}{4} & $>70$ & $\begin{array}{l}\text { D (Kurang } \\
\text { Baik) }\end{array}$ & - & - & - \\
\hline & Jumlah & & 30 & $100 \%$ & $\begin{array}{c}30 \text { Orang Peserta } \\
\text { Didik }(100 \%)\end{array}$ \\
\hline
\end{tabular}

Berdasarkan tabel 6, hasil belajar aspek pengetahuan pada siklus II dengan materi senam lantai guling depan dan sikap lilin, diperoleh data hasil belajar dengan kategori individu sebagai berikut, 6 Orang Peserta didik (20\%) dalam kategori sangat baik, 15 orang peserta didik (50\%) memperoleh nilai dengan kategori baik, 9 orang peserta didik (30\%) memperoleh nilai dengan kategori cukup, dan tidak ada peserta didik yang memperoleh nilai dengan kategori kurang.

Tabel 7.

Hasil Analisis Data Hasil Belajar Aspek Sikap Senam Lantai Guling Depan dan Sikap Lilin pada Siklus II

\begin{tabular}{cccccc}
\hline No & $\begin{array}{c}\text { Rentang } \\
\text { Skor }\end{array}$ & Predikat & $\begin{array}{c}\text { Jumlah } \\
\text { Peserta } \\
\text { Didik }\end{array}$ & Persentas & $\begin{array}{c}\text { Jumlah Ketuntasan } \\
\text { Peserta Didik }\end{array}$ \\
\hline 1 & $90-100$ & A & 5 Orang & $16,7 \%$ & 30 Orang Peserta \\
2 & $80-89$ & B & 25 Orang & $83,3 \%$ & Didik Tuntas $(100 \%)$ \\
3 & $70-79$ & C & - & - & - \\
4 & $>70$ & D & - & - & 30 Orang Peserta \\
& Jumlah & & 30 & $100 \%$ & Didik (100\%) \\
\hline
\end{tabular}

Berdasarkan tabei 7. hasil belajar aspek sikap pada siklus II dengan materi senam lantai guling depan dan sikap lilin, diperoleh data hasil belajar dengan kategori individu sebagai berikut 5 orang peserta didik $(16,7 \%)$ dengan kategori sangat baik, 25 orang peserta didik $(83,3 \%)$ memperoleh nilai dengan kategori baik, tidak ada peserta didik yang memperoleh nilai dengan kategori cukup maupun yang memperoleh nilai dengan kategori kurang. 
Tabel 8.

Hasil Analisis Data Hasil Belajar Aspek Keterampilan Senam Lantai Guling Depan dan Sikap Lilin pada Siklus II

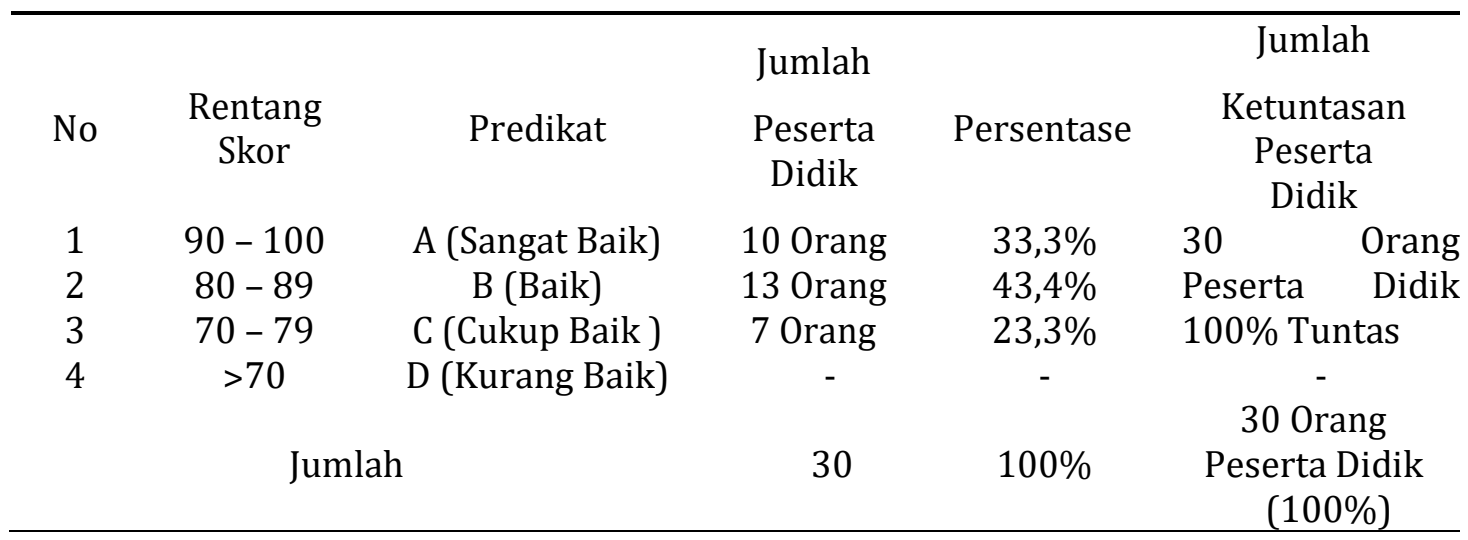

Berdasarkan tabel 8. hasil belajar aspek keterampilan pada siklus II dengan materi senam lantai guling depan dan sikap lilin, diperoleh data hasil belajar dengan kategori individu sebagai berikut, 10 orang peserta didik $(33,3 \%)$ dalam kategori sangat baik, 13 orang peserta didik $(43,4 \%)$ dalam kategori baik, 7 orang peserta didik (23,3\%) dalam kategori cukup, dan tidak ada peserta didik yang memperoleh nilai dengan kategori kurang.

Tabel. 9

Ringkasan Data Aktivitas Belajar Senam Lantai Guling Depan dan Sikap Lilin Peserta Didik Dari Siklus I sampai dengan Siklus II.

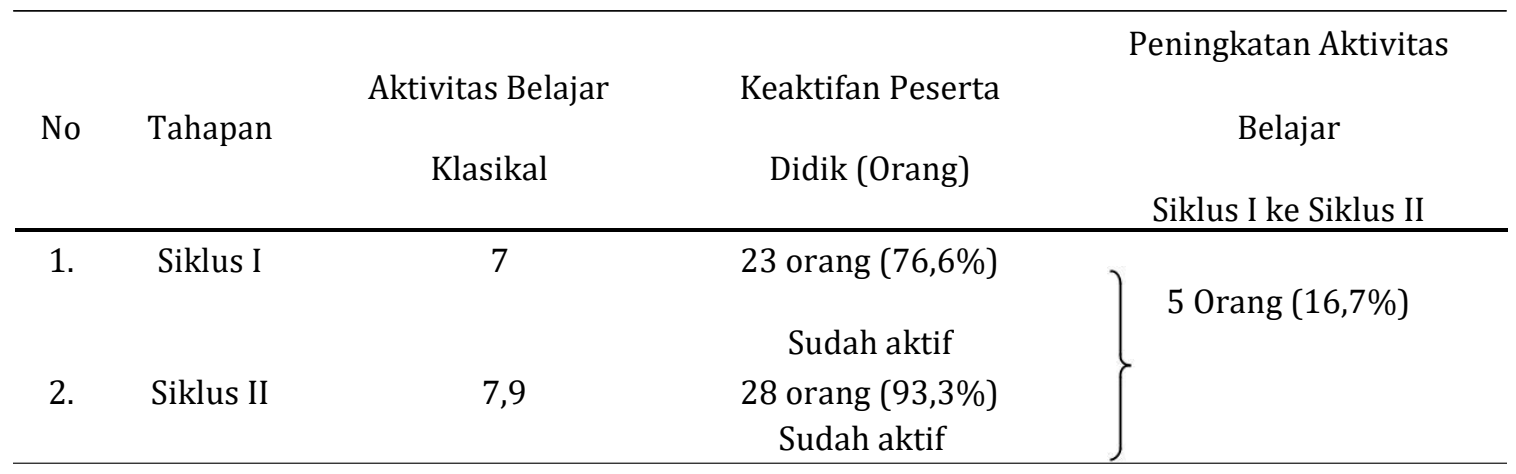

Berdasarkan Tabel 9, data aktivitas belajar senam lantai guling depan dan sikap lilin pada peserta didik kelas XII.MIPA.5 SMA Negeri 2 Singaraja dapat disampaikan bahwa, peserta didik yang sudah aktif pada siklus I, 23 orang (76,6\%). Karena pada siklus I aktivitas peserta didik masih perlu ditingkatkan, sehingga pada siklus II kembali diberikan tindakan. Setelah diberikan tindakan pada siklus II, aktivitas belajar peserta didik meningkat menjadi 28 orang (93,3\%) yang aktif . dari siklus I ke Siklus II terjadi peningkatan sebanyak 5 orang $(16,7 \%)$.

Tabel 10.

Ringkasan Data Hasil Belajar Senam Lantai Guling Depan dan Sikap Lilin Aspek Pengetahuan Peserta Didik Kelas XII.MIPA.5 SMA Negeri 2 Singaraja dari Siklus I sampai dengan Siklus II.

\begin{tabular}{|c|c|c|c|c|}
\hline \multirow{6}{*}{ No } & \multirow{6}{*}{ Tahapan } & & \multirow{6}{*}{$\begin{array}{c}\text { Ketuntasan Peserta } \\
\text { Didik }\end{array}$} & Peningkatan Hasil \\
\hline & & \multirow{5}{*}{$\begin{array}{l}\text { Ketuntasan } \\
\text { Hasil Belajar }\end{array}$} & & Belaiar Aspek \\
\hline & & & & \\
\hline & & & & Pengetahuan \\
\hline & & & & \\
\hline & & & & Siklus I ke Siklus II \\
\hline \multirow[t]{2}{*}{1.} & Siklus I & 20 Orang & Tuntas & \\
\hline & & $(66,7 \%)$ & & 10 Orang $(33,3 \%)$ \\
\hline
\end{tabular}




2. Siklus II $\left.\begin{array}{l}30 \text { Orang } \\ (100 \%)\end{array}\right\}$

Berdasarkan tabel 10 hasil analisis data hasil belajar aspek pengetahuan senam lantai guling depan dan sikap lilin pada peserta didik kelas XII.MIPA.5 SMA Negeri 2 Singaraja dapat disampaikan bahwa, persentase ketuntasan hasil belajar aspek pengetahuan peserta didik pada siklus I sebesar 20 orang $(66,7 \%)$. Karena pada siklus I masih ada peserta didik yang belum tuntas maka diberikan tindakan pada siklus II. Setelah diberikan tindakan pada siklus II ketuntasan hasil belajar peserta didik meningkat 10 orang (33,3\%) dari siklus I, sehingga jumlah ketuntasan hasil belajar aspek pengetahuan peserta didik pada siklus II menjadi 30 orang (100\%). Dari hasil analisis data tersebut, dapat dilihat peningkatan ketuntasan hasil belajar aspek pengetahuan yang terjadi dari siklus I ke siklus II sebanyak 10 orang $(33,3 \%)$.

Tabel 11

Ringkasan Data Hasil Belajar Senam Lantai Guling Depan dan Sikap Lilin Aspek Sikap Peserta Didik Kelas XII.MIPA.5 SMA Negeri 2 Singaraja dari Siklus I sampai dengan Siklus II.

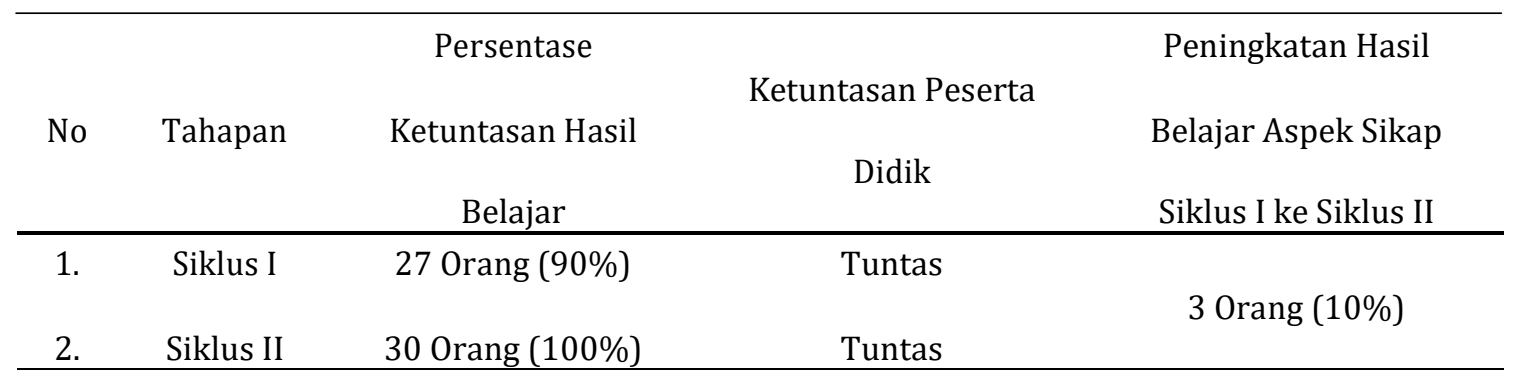

Berdasarkan tabel 11 hasil analisis data hasil belajar aspek sikap senam lantai guling depan dan sikap lilin pada peserta didik kelas XII.MIPA.5 SMA Negeri 2 Singaraja dapat disampaikan bahwa, tingkat ketuntasan hasil belajar aspek sikap peserta didik pada siklus I sebanyak 27 orang (90\%). Karena pada siklus I masih ada peserta didik yang belum tuntas, apalagi ketuntasan peeserta didik masih dalam kategori cukup, maka diberikan tindakan pada siklus II. Setelah diberikan tindakan pada siklus II ketuntasan hasil belajar aspek sikap senam lantai guling depan dan sikap lilin peserta didik meningkat sebanyak 3 orang (10\%) dari siklus I, sehingga jumlah ketuntasan hasil belajar aspek sikap peserta didik pada siklus II menjadi 30 orang (100\%). Dari hasil analisis data tersebut, dapat dilihat peningkatan ketuntasan hasil belajar aspek sikap yang terjadi dari siklus I ke siklus II sebanyak 3 orang (10\%).

Tabel 12

Ringkasan Data Hasil Belajar Senam Lantai Guling Depan dan Sikap Lilin Aspek Keterampilan Peserta Didik Kelas XII.MIPA.5 SMA Negeri 2 Singaraja dari Siklus I sampai dengan Siklus II.

\begin{tabular}{|c|c|c|c|c|}
\hline \multirow{4}{*}{ No } & \multirow{4}{*}{ Tahapan } & Persentase & \multirow{3}{*}{$\begin{array}{c}\text { Ketuntasan Peserta } \\
\text { Didik }\end{array}$} & \multirow{2}{*}{$\begin{array}{c}\text { Peningkatan Hasil } \\
\text { Belajar Aspek }\end{array}$} \\
\hline & & & & \\
\hline & & & & Keterampilan \\
\hline & & & & Siklus I ke Siklus II \\
\hline 1. & Siklus I & 25 Orang $(83,3 \%)$ & Tuntas & 5 Orang $(16,7 \%)$ \\
\hline 2. & Siklus II & 30 Orang (100\%) & Tuntas & \\
\hline
\end{tabular}

Berdasarkan tabel 12 hasil analisis data hasil belajar aspek keterampilan senam lantai guling depan dan sikap lilin pada peserta didik kelas XII.MIPA.5 SMA Negeri 2 Singaraja dapat disampaikan bahwa, tingkat ketuntasan hasil belajar aspek keterampilan peserta didik pada siklus I sebanyak 25 orang $(83,3 \%)$. Karena pada siklus I masih ada peserta didik yang belum tuntas, apalagi ketuntasan peserta didik masih dalam kategori cukup, maka diberikan tindakan pada siklus II. Setelah diberikan tindakan pada siklus II ketuntasan hasil belajar aspek keterampilan senam lantai guling depan dan sikap lilin 
peserta didik meningkat sebanyak 5 orang $(16,7 \%)$ dari siklus I, sehingga jumlah ketuntasan hasil belajar aspek keterampilan peserta didik pada siklus II menjadi 30 orang (100\%). Dari hasil analisis data tersebut, dapat dilihat peningkatan ketuntasan hasil belajar aspek keterampilan yang terjadi dari siklus I ke siklus II sebanyak 5 orang $(16,7 \%)$.

Berdasarkan hasil analisis data dari implementasi model pembelajaran kooperatif tipe NHT yang bertujuan untuk meningkatkan aktivitas dan hasil belajar senam lantai guling depan dan sikap lilin, dimana hasil penelitian aktivitas belajar peserta didik pada siklus I terhadap pembelajaran PJOK khususnya pada materi senam lantai guling depan dan sikap lilin secara klasikal berada pada kategori cukup aktif. Dengan memperhatikan aktivitas dan hasil belajar senam lantai guling depan dan sikap lilin siklus I, peneliti melanjutkan ke siklus II dengan melihat permasalahan-permasalahan pada siklus I. Hal ini terbukti dari refleksi dari siklus I yang masih terdapat permasalahan-permasalahan dalam pelaksanaan tindakan.

Adapun permasalahan-permasalahan yang dihadapi dalam pembelajaran pada siklus I yaitu: (1) peserta didik kurang mendengarkan penjelasan dari peneliti tentang senam lantai guling depan dan sikap lilin (2) peserta didik kurang memperhatikan demonstrasi yang diperagakan oleh peneliti tentang senam lantai guling depan dan sikap lilin, (3) peserta didik kurang menaruh minat dan bersemangat dalam melakukan gerakan senam lantai guling depan dan sikap lilin, (4) peserta didik belum berani mengajukan pertanyaan dan mengemukakan pendapat karena takut dan malu ditertawakan temanya jika salah terkait senam lantai guling depan dan sikap lilin, (5) kurangnya pemahaman peserta didik terhadap model pembelajaran kooperatif tipe NHT, (6) peserta didik kurang bersemangat dan besungguh-sungguh dalam melakukan senam lantai guling depan dan sikap lilin, (7) kurangnya kesempatan peserta didik dalam melakukan gerakan senam lantai guling depan dan sikap lilin sehingga hasilnya kurang maksimal.

Berdasarkan permasalahan-permasalahan yang dihadapi pada siklus I tersebut maka adapun solusinya yaitu: (1) bagi peserta didik yang kurang mendengarkan saat pemberian materi, peserta didik tersebut akan dipanggil kedepan untuk menjelaskan materi yang sudah diberikan, (2) memberikan penghargaan berupa nilai plus bagi peserta didik yang bersungguh-sungguh pada saat melakukan gerakan senam lantai guling depan dan sikap lilin sehingga pandangan dapat mengarah ke depan, (3) memberikan pertanyaan mengenai materi yang sudah disampaikan agar peserta didik tidak ragu-ragu dalam menjawab pertanyaan yang di berikan, (4) mengimplementasi model pembelajaran kooperatif tipe NHT pada peserta didik secara lebih jelas dengan memberikan lembaran tahapan-tahapan pembelajaran kooperatif tipe NHT, (5) memberikan motivasi agar peserta didik menjadi lebih bersemangat dan bersungguh-sungguh dalam mengikuti pembelajaran pada siklus II tentang senam lantai guling depan dan sikap lilin, (6) membariskan peserta didik 2 bersaf agar peserta didik yang berada di belakang dapat memperhatikan lebih jelas mengenai materi yang disampaikan, (7) membagi peserta didik menjadi jumlah kelompok yang lebih banyak sehingga jumlah peserta didik dalam satu kelompok lebih sedikit sehingga kesempatan dalam melakukan gerakan di setiap peserta didik menjadi lebih banyak.

Pembelajaran pada siklus II berlangsung sangat kondusif, peserta didik sudah mengetahui dan mampu beradaptasi dengan model pembelajaran kooperatif tipe NHT. Hal ini terlihat dari aspek aktivitas belajar peserta didik, saat peneliti memperagakan gerakan tidak lagi hanya menonton tetapi aktif bertanya terhadap penjelasan peneliti di setiap tahap gerakan yang diperagakan oleh peneliti. Rata-rata aktivitas belajar senam lantai guling depan dan sikap lilin secara klasikal tergolong aktif. Sedangakan untuk penguasaan materi senam lantai guling depan dan sikap lilin berada dalam kategori baik. Peningkatan ini tidak terlepas dari implementasi model pembelajaran kooperatif tipe NHT secara optimal dengan perbaikan-perbaikan pembelajaran sesuai dengan kekurangan-kekurangan yang terjadi pada siklus sebelumnya.

Berdasarkan uraian diatas, ini berarti tingkat ketuntasan hasil belajar senam lantai guling depan dan sikap lilin pada siklus II sudah memenuhi standar ketuntasan secara klasikal yaitu sebesar 70 sesuai dengan KKM di SMA Negeri 2 Singaraja. Peningkatan aktivitas dan hasil belajar pada siklus II tersebut dikarenakan: 1) penggunaan model pembelajaran kooperatif tipe NHT dengan pembelajaran berkelompok sudah dipahami oleh peserta didik dan 2) peneliti melakukan perbaikan berdasarkan kendala-kendala yang dialami pada siklus I.

Meskipun pelaksanaan siklus II dinyatakan berhasil, tetapi masih terdapat kendala-kendala yang dihadapi saat penerapan model pembelajaran kooperatif tipe NHT, yaitu: terbatasnya waktu pelaksanaan penelitian sehingga peserta didik kekurangan waktu untuk lebih memahami tahapan-tahapan model pembelajaran yang peneliti terapkan. Dengan adanya kendala tersebut solusi yang peneliti sarankan kepada guru yaitu untuk selanjutnya agar lebih sering menerapkan model pembelajaran kooperatif tipe NHT dalam pembelajaran PJOK, sehingga peserta didik akan semakin paham dengan struktur pembelajaran dalam model pembelajaran kooperatif tipe NHT. 
Dari sekian banyak model pembelajaran kooperatif yang ada, salah satunya adalah model pembelajaran kooperatif tipe NHT. Dimana dengan melihat aktivitas dan hasil belajar senam lantai guling depan dan sikap lilin ditemukan hasil bahwa dengan mengimplementasikan model pembelajaran kooperatif tipe NHT aktivitas dan hasil belajar peserta didik meningkat dalam materi senam lantai guling depan dan sikap lilin.

Berdasarkan data analisa hasil uraian diatas, bahwa aktivitas dan hasil belajar meningkat dikarenakan: 1) Peserta didik lebih aktif dalam mengikuti suatu proses pembelajaran dalam melakukan interaksi dengan teman sehingga pembelajaran lebih aktif dan tidak satu arah, 2) Timbulnya kerjasama antar peserta didik dengan peserta didik, tim atau teman didalam kelompoknya dapat menyelesaikan tugas gerak yang diberikan oleh guru, 3) Peserta didik memiliki rasa tanggung jawab sehingga peserta didik dapat mengerjakan tugas dengan baik dalam suatu proses pembelajaran di dalam kelompoknya, 4) Peserta didik mengamati apa yang dicontohkan oleh guru atau dari orang lain dalam suatu proses pembelajaran, 5) Rasa percaya diri peserta didik dalam melaksanakan tugas gerak yang diberikan oleh guru.

Berdasarkan penelitian yang sudah dilakukan, adapun keterbatasan dalam melakukan penelitian ini yaitu: keterbatasan waktu pelaksanaan penelitian yang dilakukan 2 siklus, agar tidak mengganggu dari kurikulum sekolah yang sudah dibuat. Berdasarkan hasil penelitian yang telah peneliti lakukan serta teori-teori pendukung hasil penelitian yang telah dipaparkan di atas dapat disimpulkan bahwa penerapan model pembelajaran kooperatif tipe NHT dapat meningkatkan aktivitas dan hasil belajar senam lantai guling depan dan sikap lilin pada peserta didik kelas XII.MIPA.5 SMA Negeri 2 Singaraja Tahun Pelajaran 2017/2018.

Penelitian yang sudah dilaksanakan ini tidaklah selalu berjalan dengan lancar sesuai dengan yang diharapkan dan yang sudah direncanakan. Karena ada kendala-kendala yang dihadapi peneliti dalam menjalankan penelitian ini. Adapun kendala-kendala yang dihadapi adalah: (a) jumlah alat-alat pendukung yang kurang dari jumlah kelompok belajar yang sudah direncanakan, (b) respon peserta didik untuk memahami materi lambat sehingga harus dijelaskan berulang-ulang.

Dari kendala-kendala yang dihadapi tersebut adapun yang dilakukan peneliti untuk memecahkannya sehingga penelitian yang dilakukan dapat berjalan dengan lancar diantaranya adalah: (a) menggunakan lapangan sekolah yang sudah ada dan alat yang dimiliki oleh peserta didik, (b) menggunakan lantai aula untuk melakukan gerakan sikap lilin untuk kekurangan Matras, dan (c) menjelaskan kembali secara berulang-ulang materi yang belum dimengerti.

\section{Simpulan}

Berdasarkan hasil analisis data dan pembahasan di atas dapat ditarik simpulan sebagai berikut. a) Aktivitas belajar senam lantai guling depan dan sikap lilin meningkat melalui implementasi model pembelajaran kooperatif tipe NHT pada siswa kelas XII.MIPA.5 SMA Negeri 2 Singaraja tahun pelajaran 2017/2018, b) Hasil belajar senam lantai guling depan dan sikap lilin meningkat melalui implementasi model pembelajaran kooperatif tipe NHT pada siswa kelas XII.MIPA.5 SMA Negeri 2 Singaraja tahun pelajaran 2017/2018.

Berdasarkan simpulan di atas, dapat dikemukakan saran-saran sebagai berikut. 1) Guru PJOK hendaknya mengimplementasi model pembelajaran kooperatif tipe NHT sebagai salah satu alternatif pembelajaran karena terbukti dapat meningkatkan aktivitas dan hasil belajar senam lantai guling depan dan sikap lilin pada pesera didik, 2) Bagi sekolah dapat dijadikan sebagai pedoman dalam pembelajaran PJOK khususnya pada materi senam lantai guling depan dan sikap lilin guna meningkatkan aktivitas dan hasil belajar, 3) Diharapkan kepada peserta didik yang dijadikan subjek penelitian selanjutnya lebih memperhatikan dan memahami pembelajaran yang diberikan agar dapat menambah wawasan pengetahuan khususunya dalam pembelajaran materi senam lantai guling depan dan sikap lilin maupun pada pembelajaran yang lain.

Guru atau peneliti lain diharapkan melakukan penelitian tindakan lanjutan dengan mengimplementasikan model pembelajaran kooperatif tipe NHT pada kompetensi dasar yang lain, untuk mengetahui bahwa model pembelajaran ini tidak hanya dapat diterapkan pada pembelajaran senam lantai, khususnya guling depan dan sikap lilin.

\section{Daftar Pustaka}

Dimiyati dan Mudjiono. 2006. Belajar dan Pembelajaran. Jakarta:Rineka Cipta.

Hamalik. 2008. Proses Belajar Mengajar. Jakarta:Bumi Aksara. 
Kanca, I Nyoman. 2010. Metodologi Penelitian Keolahragaan. Singaraja : Universitas Pendidikan Ganesha.

Nurhadi. 2004. Pembelajaran Kontekstual dan Penerapannya dalam KBK. Malang: Universitas Negeri Malang.

Nurkancana dan Sunartana. 1990. Evaluasi Hasil Belajar. Surabaya: Usaha Nasional.

Permendikbud no 65. 2013. Tentang Standar Isi Pendidikan Dasar dan Menengah. Jakarta: Kemendikbud

Sudjana. 2004. Penilaian Hasil Proses Belajar Mengajar. Bandung: Remaja Rosdakarya. Sugiyanto. 1998.

Perkembangan dan Belajar Motorik. Jakarta:Departemen Pendidikan dan Kebudayaan.

Trianto. 2007. Model-Model Pembelajaran Inovatif. Jakarta: Prestasi Pustaka Publisher.

Undiksha. 2013. Pedoman Penulisan Skripsi dan Tugas Akhir. Singaraja : Departemen Pendidikan Nasional Universitas Pendidikan Ganesha. 